\title{
KEDUDUKAN GURU SEBAGAI PENDIDIK
}

\author{
M. Yusuf Seknun \\ Fakultas Tarbiyah dan Keguruan UIN Alauddin Makassar \\ Kampus II: Jalan Sultan Alauddin Nomor 36 Samata-Gowa \\ Email: muh.yusufseknun@yahoo.co.id
}

\begin{abstract}
Abstrak:
Guru menjadi faktor yang menentukan mutu pendidikan karena guru berhadapan langsung dengan para peserta didik dalam proses pembelajaran di kelas. Guru dalam menjalankan tugas profesionalnya mempunyai tugas dan tanggung jawab yang tidak ringan. Untuk itu, guru harus memiliki dan menguasai kompetensinya dan sekaligus mengetahui hak dan kewajibannya sehingga ia menjadi sosok guru yang betul-betul profesional. Guru berkewajiban membantu perkembangan anak menuju kedewasaan yang sesuai dengan ajaran Islam. Guru sebagai jabatan profesional yang dituntut memiliki keahlian khusus, untuk itu, guru harus diberikan hak-hak tertentu sehingga mereka dapat memenuhi tugas dan tanggung jawabnya. Guru profesional dituntut memiliki kompetensi-kompetensi khusus yang meliputi; paedagogik, kepribadian, sosial, dan profesional.
\end{abstract}

\begin{abstract}
:
Teacher become a factor that determines the quality of education because they directly face to face with the students in the classroom teaching and learning process. Teacher has complicated duties and responsibilities in carrying out his/her professional duties. The teacher, therefore, should have good competence as well as know his/her own right and responsibility so that he/she becomes the real professional teacher. Teacher is obliged to help the child's development toward good maturity in accordance with Islamic teaching. As a professional position, the teacher is required to have special skills. Therefore, he/she should be given certain right so that he/she can fulfill his/her own duty and responsibility. Professional teacher is required to have specific competency, which include paedagogic, personality, social, and professional competencies.
\end{abstract}

Kata kunci:

Guru, pendidik, hak dan kewajiban, kompetensi

GURU adalah suatu sebutan bagi jabatan, posisi, dan profesi bagi seseorang yang mengabdikan dirinya dalam bidang pendidikan melalui interaksi edukatif secara terpola, formal, dan sistematis. Dalam UU RI. Nomor 14 Tahun 2005 tentang guru dan dosen pada bab I pasal 1 dinyatakan bahwa:

Guru adalah pendidik profesional dengan tugas utama mendidik, mengajar, membimbing, mengarahkan, melatih, menilai, dan mengevaluasi peserta didik pada pendidikan anak usia dini jalur pendidikan formal, pendidikan dasar, dan pendidikan menengah. ${ }^{1}$

Guru yang profesional tercermin dalam penampilan pelaksanaan pengabdian tugas-tugas yang ditandai dengan keahlian, baik dalam materi maupun metode. Di samping keahliannya, sosok guru profesional ditunjukkan melalui tanggung jawab dalam melaksanakan seluruh pengabdiannya. Guru professional hendaknya mampu 
memikul dan melaksanakan tanggung jawab sebagai guru kepada peserta didik, orang tua, masyarakat, bangsa, negara, dan agama.

Sebagai pengajar atau pendidik, guru merupakan salah satu faktor penentu keberhasilan setiap upaya pendidikan. Itulah sebabnya setiap adanya inovasi pendidikan, khususnya dalam kurikulum dan peningkatan sumber daya manusia yang dihasilkan dan upaya pendidikan, selalu bermuara pada faktor guru. Hal ini menunjukkan bahwa betapa eksisnya peran guru dalam dunia pendidikan.

Seiring dengan kemajuan teknologi informasi yang begitu pesat, guru tidak lagi sekedar bertindak sebagai penyaji informasi. Guru juga harus mampu bertindak sebagai fasilitator, motivator, dan pembimbing yang lebih banyak memberikan kesempatan kepada peserta didik untuk mencari dan mengolah sendiri informasi. ${ }^{2}$ Dengan demikian, guru juga harus senantiasa meningkatkan keahliannya dan mengikuti perkembangan ilmu pengetahuan dan teknologi sehingga mampu menghadapi berbagai tantangan.

Guru menjadi faktor yang menentukan mutu pendidikan karena guru berhadapan langsung dengan para peserta didik dalam proses pembelajaran di kelas. Di tangan guru, mutu dan kepribadian peserta didik dibentuk. Karena itu, perlu sosok guru kompeten, bertanggung jawab, terampil, dan berdedikasi tinggi. Guru adalah kurikulum berjalan. Sebaik apa kurikulum dan sistem pendidikan yang ada tanpa didukung oleh kemampuan guru, semuanya akan sia-sia. Guru berkompeten dan bertanggung jawab, utamanya dalam mengawal perkembangan peserta didik sampai ke suatu titik maksimal. Tujuan akhir seluruh proses pendampingan guru adalah tumbuhnya pribadi dewasa yang utuh.

Perkembangan dunia pendidikan yang sejalan dengan kemajuan teknologi dan globalisasi yang begitu cepat perlu diimbangi oleh kemampuan pelaku utama pendidikan, dalam hal ini guru. Bagi sebagian guru, menghadapi perubahan yang cepat dalam pendidikan dapat membawa dampak kecemasan dan ketakutan. Perubahan dan pembaruan pada umumnya membawa banyak kecemasan dan ketidaknyamanan. Implikasi perubahan dalam dunia pendidikan, bukan perkara mudah, karena mengandung konsekuensi teknis dan praktis, serta psikologis bagi guru. Misalnya, perubahan kurikulum atau perubahan kebijakan pendidikan. Perubahan itu tidak sekedar perubahan struktur dan isi kurikulum, atau sekedar perubahan isi pembelajaran, tetapi perubahan yang menuntut perubahan sikap dan perilaku dari para guru. Misalnya, perubahan karakter, mental, metode, dan strategi dalam pembelajaran.

Guru dalam menjalankan tugas profesionalnya mempunyai tugas dan tanggung jawab yang tidak ringan. Untuk itu, guru harus memiliki dan menguasai kompetensinya dan sekaligus mengetahui hak dan kewajibannya sehingga menjadi sosok guru yang betul-betul profesional.

Dari uraian di atas, selanjutnya dalam makalah ini akan dibahas lebih lanjut uraian tentang pengertian, tugas dan tanggung jawab, hak dan kewajiban, serta kompetensi guru secara berturut-turut. 


\section{PEMBAHASAN}

\section{Pengertian Guru}

Guru dalam Kamus Besar Bahasa Indonesia berarti orang yang pekerjaannya (mata pencahariannya, profesinya) mengajar. ${ }^{3}$ Pengertian ini memberi kesan bahwa guru adalah orang yang melakukan kegiatan dalam bidang mengajar. Istilah guru sinonim dengan kata pengajar dan sering dibedakan dengan istilah pendidik. Perbedaan ini dalam pandangan Muh. Said dalam Abidin Ibnu Rusn dipengaruhi oleh kebiasaan berpikir orang barat, khususnya orang Belanda yang membedakan kata onderwys (pengajaran) dengan kata opveoding (pendidikan). Pandangan ini diikuti oleh tokoh-tokoh pendidikan di dunia timur, termasuk tokoh-tokoh pendidikan di kalangan muslim. ${ }^{4}$

Abuddin Nata dalam Filsafat Pendidikan Islam mengemukakan istilah-istilah yang berkaitan dengan penamaan atas aktifitas mendidik dan mengajar. Ia lalu menyimpulkan bahwa keseluruhan istilah-istilah tersebut terhimpun dalam kata pendidik. ${ }^{5}$ Hal ini disebabkan karena keseluruh istilah itu mengacu kepada seseorang yang memberikan pengetahuan, keterampilan atau pengalaman kepada orang lain.

Selanjutnya, guru menurut Zahara Idris dan Lisma Jamal dalam Muhamad Idris adalah orang dewasa yang bertanggung jawab memberikan bimbingan kepada peserta didik dalam hal perkembangan jasmani dan rohaniya untuk mencapai tingkat kedewasaan, memenuhi tugas sebagai makhluk Tuhan, makhluk individu yang mandiri, dan makhluk sosial. ${ }^{6}$

Al-Gazali tidak membedakan kata pengajaran dan pendidikan sehingga guru dan pendidik juga tidak dibedakan. ${ }^{7} \mathrm{Hal}$ ini senada dengan pandangan Muhibbuddin Ahmad Abi Salih yang memandang bahwa sesungguhnya istilah tarbiyyah dan ta'lim dalam pendidikan Islam sama saja. ${ }^{8}$ Ia berpendapat demikian karena melihat kenyataan bahwa di dalam al-Qur'an kedua kata itu digunakan untuk mengungkapkan kegiatan pengajaran dan pendidikan yang meliputi semua segi perkembangan manusia. Dengan demikian, guru dan pendidik sama saja.

Seorang yang berkecimpung dalam pendidikan harus memiliki kepribadian yang mencerminkan seorang pendidik. Tuntutan terhadap kepribadian sebagai pendidik kadang-kadang dirasakan lebih berat dibandingkan profesi lainnya. Guru merupakan seorang yang harus bisa digugu dan ditiru. ${ }^{9}$ Digugu artinya segala sesuatu yang disampaikan senantiasa dipercaya dan diyakini sebagai kebenaran oleh semua muridnya. Segala ilmu pengetahuan yang datangnya dari sang guru dijadikan sebagai suatu kebenaran yang tidak perlu dibuktikan atau diteliti lagi. Ditiru artinya menjadi suri teladan dan panutan bagi muridnya, mulai dan cara berpikir, cara berbicara hingga cara berperilaku sehari-hari. Dengan demikian, guru memiliki peran yang sangat besar dalam pelaksanaan pembelajaran atau pendidikan.

\section{Tugas dan Tanggung Jawab Guru}

Manusia dapat disebut sebagai manusia yang bertanggung jawab apabila mampu membuat pilihan dan membuat keputusan atas dasar nilai-nilai dan norma-norma 
tertentu, baik yang bersumber dari dalam dirinya maupun yang bersumber dari lingkungan sosial. ${ }^{10}$ Dengan demikian, dapat dikatakan bahwa manusia bertanggung jawab apabila mampu bertindak atas dasar keputusan moral.

Setiap guru profesional harus memenuhi persyaratan sebagai manusia yang bertanggung jawab dalam bidang pendidikan, tetapi di pihak lain dia juga mengembang sejumlah tanggung jawab dalam bidang pendidikan. Guru sebagai pendidik bertanggung jawab mewariskan nilai-nilai dan norma-norma kepada generasi muda sehingga terjadi proses konservasi nilai, bahkan melalui proses pendidikan diusahakan terciptanya nilai-nilai baru.

Kehadiran guru dalam proses pembelajaran sebagai sarana mewariskan nilainilai dan norma-norma masih tetap memegang peranan yang sangat penting. Peranan guru dalam pembelajaran tidak bisa digantikan oleh mesin-mesin komputer yang modern. Masih terlalu banyak unsur manusiawi, sikap, sistem nilai, perasaan, motivasi, kebiasaan dan lain-lain. Seorang guru akan sukses melaksanakan tugas apabila ia profesional dalam bidang keguruannya. Selain itu, tugas seorang guru mulia dan mendapat derajat yang tinggi yang diberikan Allah swt. disebabkan mereka mengajarkan ilmu kepada orang lain.

Salah satu faktor yang paling menentukan dalam proses pembelajaran di kelas adalah guru. Tugas guru yang paling utama adalah mengajar dan mendidik. Sebagai pengajar guru berperan aktif (medium) antara peserta didik dengan ilmu pengetahuan. ${ }^{11}$ Secara umum dapat dikatakan bahwa tugas dan tanggung jawab yang harus dilaksanakan oleh guru adalah mengajak orang lain berbuat baik. Tugas tersebut identik dengan dakwah islamiyah yang bertujuan mengajak umat Islam untuk berbuat baik. Allah swt. berfirman di dalam Q.S. Ali Imran/3 :104:

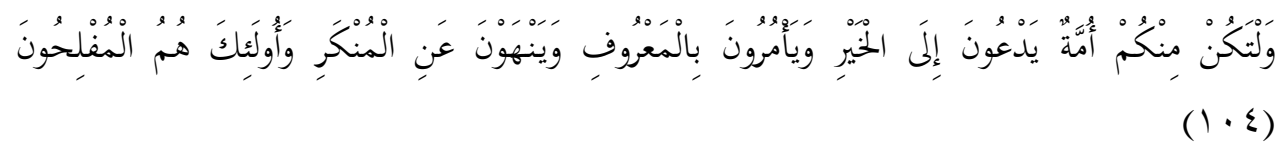

Dan hendaklah ada di antara kamu segolongan umat yang menyeru kepada kebajikan, menyuruh kepada yang makruf dan mencegah dari yang munkar, mereka itulah orangorang yang beruntung. ${ }^{12}$

Profesi seorang guru juga dapat dikatakan sebagai penolong orang lain, karena dia menyampaikan hal-hal yang baik sesuai dengan ajaran Islam agar orang lain dapat melaksanakan ajaran Islam. Dengan demikian, akan tertolonglah orang lain dalam memahami ajaran Islam. Sayyid Quthub mengatakan bahwa ayat mengharuskan sekelompok orang untuk menyuruh berbuat baik dan melarang berbuat mungkar. ${ }^{13}$ Dalam Tafsir Al-Azhar, diterangkan bahwa suatu umat yang menyediakan dirinya untuk mengajak atau menyeru manusia berbuat kebaikan, menyuruh berbuat yang makruf yaitu yang patut, pantas, sopan, dan mencegah dari yang mungkar. ${ }^{14}$

Berdasarkan ayat dan tafsir di atas dapat dipahami bahwa dalam melaksanakan tugas dan tanggung jawabnya, guru berkewajiban membantu perkembangan anak menuju kedewasaan yang sesuai dengan ajaran Islam. Apalagi karena di dalam tujuan pendidikan terkandung unsur tujuan yang bersifat agamis, yaitu agar terbentuk manusia yang beriman dan bertakwa terhadap Tuhan Yang Maha Esa. 
Agama datang menuntun manusia dan memperkenalkan mana yang makruf dan mana yang mungkar. Oleh karena itu, hendaklah guru menggerakkan peserta didik kepada yang makruf dan menjauhi yang mungkar, supaya mereka bertambah tinggi nilainya, baik di sisi manusia maupun di hadapan Allah.

Bila diperhatikan lebih jauh, tugas dan tanggung jawab yang mestinya dilaksanakan oleh guru yang telah dijelaskan pada firman Allah di atas intinya adalah mengajak manusia melaksanakan perintah Allah dan menjauhi larangan-Nya. M. Ja'far menegaskan, “Tugas dan tanggung jawab guru menurut agama Islam dapat diidentifikasikan sebagai tugas yang harus dilakukan oleh ulama, yaitu menyuruh yang makruf dan mencegah yang mungkar. ${ }^{15} \mathrm{Hal}$ ini menunjukkan adanya kesamaan tugas yang dilaksanaan guru dengan muballigh/da'i, melaksanakan tugasnya melalui jalur pendidikan non formal. Rasulullah saw. bersabda:

$$
\text { عن عبد الله بن عمرو أن النى صلى الله عليه وسلم قال بلغوا عني ولوآية } 16
$$

Dari Abdullah bin Amr, dia berkata, Nabi saw. Bersabda:Sampaikanlah dan ajaranku walaupun satu ayat. (HR. al-Bukhari)

Berdasarkan hadis di atas dapat dipahami bahwa tugas dan tanggung jawab yang harus dilaksanakan oleh orang yang mengetahui, termasuk pendidik/guru, adalah menyampaikan apa yang diketahuinya (ilmu) kepada orang yang tidak mengetahui. Guru merupakan pemimpin pendidikan dalam melaksanakan proses pembelajaran. Guru harus dapat bertanggung jawab terhadap Allah atas kepemimpinannya sebagaimana terdapat dalam hadis yang berbunyi:

$$
\text { رعبد الله بن عمر يقول سمعت رسول الله صلى الله عليه وسلم يقول كلكم راع و كلكم مسئول عن }
$$

Abdullah bin Umar berkata: Saya mendengar Rasulullah saw. Bersabda: Setiap kamu adalah pemimpin dan setiap kamu akan dimintai pertanggungjawaban atas kepemimpinannya. (H.R. al-Bukhari)

Berdasarkan hadis di atas dapat dipahami bahwa tanggung jawab dalam Islam bersifat pribadi dan sosial. Dalam pendidikan formal, guru adalah pemimpin di dalam kelas yang bertanggung jawab tidak hanya terhadap perbuatannya, tetapi juga terhadap perbuatan orang-orang yang berada di bawah perintah dan pengawasannya yaitu peserta didik.

Apabila dilihat dari rincian tugas dan tanggung jawab yang harus dilaksanakan oleh guru, al-Abrasyi yang mengutip pendapat al-Ghazali mengemukakan bahwa:

1. Guru harus menaruh rasa kasih sayang terhadap murid dan memberlakukan mereka seperti perlakuan anak sendiri;

2. Tidak mengharapkan balas jasa ataupun ucapan terima kasih, tetapi bermaksud dengan mengajar itu mencari keridhaan Allah dan mendekatkan diri kepada Tuhan;

3. Memberikan nasehat kepada murid pada tiap kesempatatan, bahkan menggunakan setiap kesempatan itu untuk menasehati dan menunjukinya; 
4. Mencegah murid dari akhlak yang tidak baik dengan jalan sindiran jika mungkin dan dengan jalan terus terang, dengan jalan halus, dan tidak mencela;

5. Seorang guru harus menjalankan ilmunya dan jangan berlainan kata dengan perbuatannya. ${ }^{18}$

Ahmad Tafsir membagi tugas-tugas yang dilaksanakan oleh guru yaitu:

1. Wajib mengemukakan pembawaan yang ada pada anak dengan berbagai cara seperti observasi, wawancara, melalui pergaulan, angket dan sebagainya;

2. Berusaha menolong peserta didik mengembangkan pembawaan yang baik dan menekankan pembawaan yang buruk agar tidak berkembang;

3. Memperlihatkan kepada peserta didik tugas orang dewasa dengan cara memperkenalkan berbagai keahlian, keterampilan agar mereka memilikinya dengan cepat;

4. Mengadakan evaluasi setiap waktu untuk mengetahui apakah perkembangan peserta didik berjalan dengan baik;

5. Memberikan bimbingan dan penyuluhan tatkala peserta didik melalui kesulitan dalam mengembangkan potensinya. ${ }^{19}$

Berdasarkan pendapat yang dikemukakan di atas dapat diketahui bahwa tugas dan tanggung jawab guru bukan hanya mengajar atau menyampaikan kewajiban kepada peserta didik, akan tetapi juga membimbing mereka secara keseluruhan sehingga terbentuk kepribadian muslim.

Sehubungan dengan hal itu, Zainal Abidin menegaskan bahwa tugas dan tanggung jawab utama yang harus dilaksanakan oleh guru, terutama guru pendidikan agama Islam adalah membimbing dan mengajarkan seluruh perkembangan kepribadian peserta didik pada ajaran Islam. ${ }^{20}$ Menurut al-Gazali, guru harus memiliki akhlak yang baik karena peserta didik selalu melihat pendidiknya sebagai contoh yang harus diikutinya. ${ }^{21}$

Sedangkan Nur Uhbayati mengemukakan tugas dan tanggung jawab yang harus dilaksanakan oleh pendidik (guru) antara lain:

1. Membimbing peserta didik kepada jalan yang sesuai dengan ajaran agama Islam;

2. Menciptakan situasi pendidikan keagamaan yaitu suatu keadaan di mana tindakan-tindakan pendidikan dapat berlangsung dengan hasil yang memuaskan sesuai dengan tuntutan ajaran Islam. ${ }^{22}$

Pada sisi lain, Samsul Nizar mengungkapkan rangkaian tugas guru dalam mendidik, yaitu "Rangkaian mengajar, memberikan dorongan, menguji, menghukum, memberikan contoh, dan membiasakan". ${ }^{23}$ Imam Barnadib menambahkan bahwa "Tugas guru terkait dengan perintah, larangan, menasehati, hadiah, pemberian kesempatan, dan menutup kesempatan". ${ }^{24}$ Dengan demikian, dapat dipahami bahwa tugas guru bukan hanya sekedar mengajar. Di samping itu, ia bertugas sebagai motivator dan fasilitator dalam proses pembelajaran, sehingga seluruh potensi peserta didik dapat teraktualisasi secara baik dan dinamis.

\section{Hak dan Kewajiban Guru}

Guru sebagai jabatan profesional yang dituntut memiliki keahlian khusus, diharapkan betul-betul mengarahkan seluruh perhatiannya agar selalu dapat melaksana- 
kan tugas profesionalnya dengan penuh tanggung jawab. Untuk itu, guru harus diberikan hak-hak tertentu sehingga mereka dapat memenuhi tugas dan tanggung jawabnya.

Di dalam UU R.I. No. 14 Tahun 2005 tentang Guru dan Dosen bab IV pasal 14 ayat 1 disebutkan bahwa dalam melaksanakan tugas keprofesionalan guru berhak:

1. Memperoleh penghasilan di atas kebutuhan hidup minimun dan jaminan kesejahteraan sosial;

2. Mendapatkan promosi dan penghargaan sesuai dengan tugas dan prestasi kerja;

3. Memperoleh perlindungan dalam melaksanakan tugas dan hak atas kekayaan intelektual;

4. Memperoleh kesempatan untuk meningkatkan kompetensi;

5. Memperoleh dan memanfaatkan sarana dan prasarana pembelajaran untuk menjaga kelancaran tugas keprofesionalan;

6. Memiliki kebebasan dalam memberikan penilaian dan ikut menentukan kelulusan, penghargaan, dan/atau sanksi kepada peserta didik sesuai dengan kaidah pendidikan, kode etik guru, dan peraturan perundang-undangan;

7. Memperoleh rasa aman dan jaminan keselamatan dalam melaksanakan tugas;

8. Memiliki kebebasan untuk berserikat dalam organisasi profesi;

9. Memiliki kesempatan untuk berperan dalam penentuan kebijakan pendidikan;

10.Memperoleh kesempatan untuk mengembangkan dan meningkatkan kualifikasi akademik dan kompetensi; dan/atau

11.Memperoleh pelatihan dan pengembangan profesi dalam bidangnya. ${ }^{25}$

Guru profesional dituntut memiliki kompetensi-kompetensi khusus. Selain itu, guru juga dituntut melaksanakan kewajiban-kewajiban yang dibebankan kepadanya. Di dalam pasal 20 UU R.I. No. 14 Tahun 2005 tentang Guru dan Dosen disebutkan bahwa guru dalam melaksanakan tugasnya mempunyai beberapa kewajiban, yaitu:

1. Merencanakan pembelajaran, melaksanakan proses pembelajaran yang bermutu, serta menilai dan mengevaluasi hasil pembelajaran;

2. Meningkatkan dan mengembangkan kualifikasi akademik dan kompetensi secara berkelanjutan sejalan dengan perkembangan ilmu pengetahuan, teknologi, dan seni;

3. Bertindak objektif dan tidak diskriminatif atas dasar pertimbangan jenis kelamin, agama, suku, ras, dan kondisi fisik tertentu, atau latar belakang keluarga, dan status sosial ekonomi peserta didik dalam pembelajaran;

4. Menjunjung tinggi peraturan perundang-undangan hukum, dan kode etik guru, serta nilai-nilai agama dan etika; dan

5. Memelihara dan memupuk persatuan dan kesatuan bangsa. ${ }^{26}$

Dengan melaksanakan kewajiban-kewajiban sebagaimana diamanatkan oleh undang-undang tersebut di atas, seorang guru akan tetap dapat eksis di tengahtengah perkembangan ilmu pengetahuan dan teknologi yang semakin pesat. Demikian pula para peserta didik akan semakin hormat kepadanya karena mereka melihat guru mereka sebagai sosok yang senantiasa dapat ditiru dan digugu. 


\section{Kompetensi Guru}

Di dalam Kamus Besar Bahasa Indonesia, disebutkan bahwa kompetensi berarti kewenangan (kekuasaan) untuk menentukan (memutuskan) sesuatu. ${ }^{27} \mathrm{~W}$. Robert Houston yang dikutip oleh Abdul Mujib dan Jusuf Mudzakkir mengatakan bahwa kompetensi adalah suatu tugas yang memadai atau pemilikan pengetahuan, keterampilan, dan kemampuan yang dituntut oleh jabatan seseorang. ${ }^{28}$ Dari pengertian tersebut dipahami bahwa suatu pekerjaan yang bersifat profesional memerlukan beberapa bidang ilmu yang secara sengaja harus dipelajari dan kemudian diaplikasikan bagi kepentingan umum. Pekerjaan profesional memerlukan kemampuan dan keahlian khusus dalam melaksanakan profesinya.

Guru sebagai pekerjaan profesional juga memerlukan kemampuan dan keahlian khusus dalam menjalankan tugasnya yang biasa disebut kompetensi guru. Kompetensi guru berupa seperangkat pengetahuan, keterampilan, dan perilaku yang harus dimiliki, dihayati, dan dikuasai oleh seorang guru agar dapat melaksanakan tugas-tugas keprofesionalannya. Dengan penguasaan kompetensi-kompetensi itu, diharapkan dapat diwujudkan pencapaian tujuan pendidikan nasional.

Di dalam UU R.I. No. 14 Tahun 2005 tentang Guru dan Dosen disebutkan bahwa kompetensi meliputi kompetensi pedagogik, kepribadian, sosial, dan profesional. ${ }^{29}$ Selanjutnya di dalam penjelasan undang-undang ini disebutkan bahwa kompetensi pedagogik adalah kemampuan mengelola pembelajaran peserta didik, kompetensi kepribadian adalah kemampuan kepribadian yang mantap, berakhlak mulia, arif, dan berwibawa serta menjadi teladan bagi peserta didik. Lebih lanjut dikemukakan bahwa kompetensi profesional guru adalah kemampuan penguasaan materi pelajaran secara luas dan mendalam, sedangkan kompetensi sosial berarti kemampuan guru untuk berkomunikasi dan berinteraksi secara efektif dan efisien dengan peserta didik, sesama guru, orang tua/wali peserta didik, dan masyarakat sekitar. ${ }^{30}$

Keempat kompetensi tersebut secara teoritis dapat dipisah-pisahkan satu sama lain. Namun, secara praktis keempat kompetensi itu tidak mungkin dipisah-pisahkan. Keempatnya saling menjalin secara terpadu dalam diri seorang guru.

\section{Kompetensi Pedagogis}

Kompetensi pedagosis adalah seperangkat kemampuan dan keterampilan (skill) yang berkaitan dengan interaksi pembelajaran antara guru dan peserta didik dalam kelas. Kompetensi pedagogis ini meliputi kemampuan guru dalam menjelaskan materi, melaksanakan metode pembelajaran, memberikan pertanyaan, menjawab pertanyaan, mengelola kelas, dan melaksanakan evaluasi.

\section{Kompetensi Kepribadian}

Kompetensi kepribadian adalah seperangkat kemampuan dan karakteristik personal yang memcerminkan realitas sikap dan perilaku guru dalam melaksanakan tugas-tugasnya dalam kehidupan sehari-hari. Kompetensi kepribadian ini melahirkan ciri-ciri guru yaitu, sabar, tenang, bertanggung jawab, demokratis, ikhlas, cerdas, menghormati orang lain, stabil, ramah, tegas, berani, kreatif, inisiatif, dan lain-lain. 


\section{Kompetensi Sosial}

Kompetensi sosial adalah seperangkat kemampuan dan keterampilan yang terkait dengan hubungan atau interaksi dengan orang lain. Artinya, guru harus dituntut memiliki keterampilan berinteraksi dengan masyarakat, khususnya dalam mengidentifikasi, menganalisis, dan menyelesaikan problem masyarakat. Dalam realitas masyarakat, guru masih menjadi sosok elit masyarakat yang dianggap memiliki otoritas moral cukup besar. Salah satu konsekuensi agar peran itu tetap melekat dalam diri guru adalah guru harus memiliki kemampuan berhubungan dan berkomunikasi dengan orang lain.

\section{Kompetensi Profesional}

Kompetensi profesional adalah seperangkat kemampuan dan keterampilan terhadap penguasaan materi pelajaran secara mendalam, utuh, dan komprehensif. ${ }^{31} \mathrm{Gu}-$ ru yang memiliki kompetensi profesional tidak cukup hanya memiliki penguasaan materi secara formal, tetapi juga harus memiliki kemampuan terhadap materi ilmu lain yang memiliki keterkaitan dengan pokok bahasan mata pelajaran tertentu. Misalnya, guru fikih yang mengajar pokok bahasan nikah tidak cukup menguasai materi yang berkaitan dengan normativitas fikih, melainkan juga harus menguasai dan memahami materi nikah yang berkaitan dengan perkembangan penduduk. Konsekuensinya, guru tersebut harus menguasai materi yang berkaitan dengan kependudukan. Guru tafsir yang mengajar pokok bahasan kerusakan di muka bumi, tidak cukup hanya menjelaskan terminologi kerusakan secara normatif. Tetapi, kerusakan harus dilihat dari aspek sosiologis, psikologis, geografis, dan kultural. Guru akan mampu menjelaskan materi itu jika menguasai materi sosiologi atau antropologi.

\section{SIMPULAN}

Guru adalah pendidik profesional dengan tugas utama mendidik, mengajar, membimbing, mengarahkan, melatih, menilai, dan mengevaluasi peserta didik pada pendidikan anak usia dini jalur pendidikan formal, pendidikan dasar, dan pendidikan menengah. Guru profesional hendaknya mampu memikul dan melaksanakan tanggung jawab sebagai guru kepada peserta didik, orang tua, masyarakat, bangsa, negara, dan agamanya. Tugas dan tanggung jawab guru adalah mengajar atau menyampaikan kewajiban kepada peserta didik. Selain itu, juga membimbing mereka secara keseluruhan sehingga terbentuk kepribadian muslim.

Dalam menjalankan tugas dan tanggung jawabnya, guru mempunyai hak-hak berupa penghasilan, promosi, kesempatan meningkatkan kompetensi, memanfaatkan sarana dan prasarana pembelajaran, kebebasan memberikan penilaian, memperoleh rasa aman, kebebasan berserikat, kesempatan berperan dalam penentuan kebijakan pendidikan, mengembangkan kualifikasi dan kompetensi, dan pelatihan dan pengembangan profesi.

Dengan hak-hak tersebut, guru berkewajiban merencanakan pembelajaran secara baik, mengembangkan kualifikasi dan kompetensinya secara berkesinambung- 
an, bertindak objektif, menjunjung tinggi peraturan, dan memelihara persatuan dan kesatuan bangsa.

Sebagai guru yang profesional, ia harus memiliki keahlian khusus yang disebut kompetensi dalam menjalankan tugas-tugas profesionalnya. Keahlian tersebut meliputi kompetensi pedagogik, kompetensi kepribadian, kompetensi sosial, dan kompetensi profesional. Keempat kompetensi tersebut saling terjalin secara padu dalam diri seorang guru.

\section{CATATAN AKHIR}

1. Redaksi Sinar Grafika, Undang-undang Guru dan Dosen (UU RI No. 14 Th. 2005), cet. II; Jakarta: Sinar Grafika, 2009, h. 3.

2. Lihat Hamzah B. Uno, Profesi Kependidikan, Problema, Solusi, dan Reformasi Pendidikan di Indonesia, cet. IV; Jakarta: Bumi Aksara, 2009, h. 16-17.

3. Pusat Bahasa Departemen Pendidikan Nasional, Kamus Besar Bahasa Indonesia, Edisi Ketiga, cet. III; Jakarta: Balai Pustaka, 2005, h. 509.

4. Lihat Abidin Ibnu Rusn, Pemikiran Al-Ghazali tentang Pendidikan, cet. II; Yogyakarta: Pustaka Pelajar, 2009, h. 62-63.

5. Lihat Abuddin Nata, Filsafat Pendidikin Islam, Jilid I, cet. I; Jakarta: Logos Wacana Ilmu, 1997, h. 61.

6. Lihat Muhamad Idris, Kiat Menjadi Guru Profesional, cet. I; Yogyakarta: Ar-Ruzz Media, 2008, h. 49 .

7. Lihat Abidin Ibnu Rusn, op. cit., h. 63.

8. Lihat Muhibb al-Dīn Ahmad Abī Shalihh, et al., Mudzakkirah Mu'jizah fi al-Tarbiyyah alIslāmiyyah wa Thuruq Tadrīs al- 'Ulūm al-Dìniyyah wa al-Arabiyyah, Al-Madīnah alMunawwarah: Mathābi' al-Jāmi' ah al-Islāmiyyah, 1410 H., h. 10.

9. Lihat E. Mulyasa, Menjadi Guru Profesional, Menciptakan Pembelajaran Kreatif dan Menyenangkan, cet. VII; Bandung: Remaja Rosda Karya, 2008, h. 48.

10. Lihat Oemar Hamalik, Pendidikan Guru Berdasarkan Pendekatan Kompetensi, cet. V; Jakarta: Bumi Aksara, 2008, h. 39.

11. Lihat Muhaimin dkk., Strategi Belajar Mengajar (Penerapan dalam Pendidikan Agama), Surabaya: Citra Media, 1996, h. 54.

12. Departemen Agama RI., Al-Qur 'an dan Terjemahnya, Semarang: Toha Putra, t.th., h. 50.

13. Lihat Sayyid Quthub, Fì Dzilāl al-Qur'ān, Juz I, CD al-Maktabah al-Syāmilah, h. 410.

14. Lihat Hamka, Tafsir Al-Azhar, Juz IV, Jakarta: Pustaka Panjimas, 1983, h. 31.

15. M. Ja'far, Beberapa Aspek Pendidikan Islam, Surabaya: Al-Ikhlas, 1992, h. 272.

16. Abū 'Abdillāh Muhammad ibn Ismā'ī ibn Ibrāhīm ibn al-Mugīrah ibn Bardarbah al-

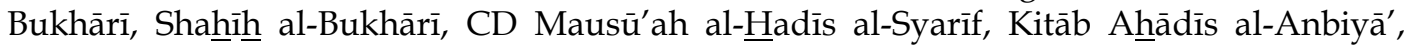
nomor 3202.

17. Ibid., Kitāb al-Jum'ah, nomor 844.

18. Lihat Muhammad Athiyah Al-Abrasyi, Al-Tarbiyyah al-Islämiyyah, ter. Bustami A. Gani dan Djohar Bahry, Dasar-dasar Pokok Pendidikan Islam, cet. IV; Jakarta: Bulan Bintang, 1979, h. 150-151.

19. Lihat Ahmad Tafsir, Ilmu Pendidikan dalam Perspektif Islam, Bandung: Remaja Rosdakarya, 1994, h. 79.

20. Lihat Zainal Abidin, Kepribadian Muslim, Semarang: Aneka Ilmu, 1989, h. 29.

21. Lihat Zuhairini dkk, Filsafat Pendidikan Islam, Jakarta: Bumi Aksara, 1995, h 170.

22. Lihat Nur Uhbayati, Ilmu Pendidikan Islam, Bandung: Pustaka Setia, 1997, h. 72. 
23. Samsul Nizar, Filsafat Pendidikan Islam, Pendekatan Teoritis dan Praktis, Jakarta: Ciputat Pers, 1993, h. 44.

24. Lihat Sutari Imam Barnadib, Pengantar Ilmu Pendidikan Sistematis, Yogyakarta: Andi Ofset, 1993, h. 40.

25. Lihat Redaksi Sinar Grafika, op. cit., h. 10-11.

26. Lihat Ibid., h. 14-15.

27. Pusat Bahasa Departemen Pendidikan Nasional, op. cit., h. 795.

28. Abdul Mujib dan Jusuf Mudzakkir, Ilmu Pendidikan Islam, cet. I; Jakarta: Kencana, 2006, h. 93.

29. Redaksi Sinar Grafika, op. cit., h. 9.

30. Lihat Ibid., h. 56-57.

31. Lihat Saekhan Muchith, Pembelajaran Kontekstual, cet. I; Semarang: Rasail Media Group, 2008, h. 148-149.

\section{DAFTAR PUSTAKA}

Abidin, Zainal, Kepribadian Muslim. Semarang: Aneka Ilmu, 1989.

al-Abrasyi, Muhammad Athiyah, Al-Tarbiyyah al-Islāmiyyah, ter. Bustami A. Gani dan Djohar Bahry, Dasar-dasar Pokok Pendidikan Islam, cet. IV; Jakarta: Bulan Bintang, 1979.

al-Bukhārī, Abū 'Abdillāh Muhammad ibn Ismā'î ibn Ibrāhīm ibn al-Mugīrah ibn Bardarbah,

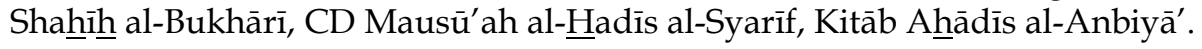

Barnadib, Sutari Imam, Pengantar Ilmu Pendidikan Sistematis, Yogyakarta: Andi Ofset, 1993.

Departemen Agama RI., Al-Qur 'an dan Terjemahnya, Semarang: Toha Putra, t.th.

E. Mulyasa, Menjadi Guru Profesional, Menciptakan Pembelajaran Kreatif dan Menyenangkan, cet. VII; Bandung: Remaja Rosda Karya, 2008.

Hamalik, Oemar, Pendidikan Guru Berdasarkan Pendekatan Kompetensi, cet. V; Jakarta: Bumi Aksara, 2008.

Hamka, Tafsir Al-Azhar, Juz IV, Jakarta: Pustaka Panjimas, 1983.

Ibnu Rusn, Abidin, Pemikiran Al-Ghazali tentang Pendidikan, cet. II; Yogyakarta: Pustaka Pelajar, 2009.

Idris, Muhamad, Kiat Menjadi Guru Profesional, cet. I; Yogyakarta: Ar-Ruzz Media, 2008.

M. Ja'far, Beberapa Aspek Pendidikan Islam, Surabaya: Al-Ikhlas, 1992.

Muchith, Saekhan, Pembelajaran Kontekstual, cet. I; Semarang: Rasail Media Group, 2008.

Muhaimin dkk., Strategi Belajar Mengajar, (Penerapan dalam Pendidikan Agama) Surabaya: Citra Media, 1996.

Mujib, Abdul dan Jusuf Mudzakkir, Ilmu Pendidikan Islam, cet. I; Jakarta: Kencana, 2006.

Nata, Abuddin, Filsafat Pendidikin Islam, Jilid I., cet. I; Jakarta: Logos Wacana Ilmu, 1997.

Nizar, Samsul, Filsafat Pendidikan Islam, Pendekatan Teoritis dan Praktis, Jakarta: Ciputat Pers, 1993.

Pusat Bahasa Departemen Pendidikan Nasional, Kamus Besar Bahasa Indonesia, Edisi Ketiga, cet. III; Jakarta: Balai Pustaka, 2005.

Quthub Sayyid, Fī Dzilāl al-Qur'ān, Juz I, CD al-Maktabah al-Syāmilah

Redaksi Sinar Grafika, Undang-undang Guru dan Dosen (UU RI No. 14 Th. 2005,) cet. II; Jakarta: Sinar Grafika, 2009.

Shalihh, Muhibb al-Dīn Aḥmad Abī, et al., Mudzakkirah Mu'jizah fi al-Tarbiyyah al-Islāmiyyah wa Thuruq Tadrīs al- 'Ulūm al-Diniyyah wa al-Arabiyyah, Al-Madīnah al-Munawwarah: Mathābi' al-Jāmi'ah al-Islāmiyyah, $1410 \mathrm{H}$.

Tafsir, Ahmad, Ilmu Pendidikan dalam Perspektif Islam, Bandung: Remaja Rosdakarya, 1994. 
Uhbayati, Nur, Ilmu Pendidikan Islam, Bandung: Pustaka Setia, 1997.

Uno, Hamzah B., Profesi Kependidikan, Problema, Solusi, dan Reformasi Pendidikan di Indonesia, cet. IV; Jakarta: Bumi Aksara, 2009.

Zuhairini dkk, Filsafat Pendidikan Islam, Jakarta: Bumi Aksara, 1995. 